\title{
К ВОПРОСУ О ПРОИСХОЖДЕНИИ ВАЙВАРАСКИХ СИНИХ ГОР (СЕВЕРО-ВОСТОЧНАЯ ЭСТОНИЯ)
}

Освобождение территории Эстонии от ледникового покрова последнего оледенения сопровождалось более или менее значительными остановками и кратковременными подвижками края ледника. В последнем случае местами образовались напорные конечныеморены, из которых в Эстонии наиболее известны Синие горы в $20 \mathrm{kM} \mathrm{к} \mathrm{западу} \mathrm{от}$ г. Нарвы (табл. I, $\boldsymbol{i}$ ).

Несмотря на многочисленные исследования, у геологов до сих пор отсутствует единое мнение о генезисе Синих гор. Большинство исследователей (Hausen, 1913; Granö, 1922; Jaansoon-Orviku, 1926; Tammekann, 1926; Марков, 1931) рассматривают их как. напорные конечные морены, в строении которых принимают участие крупные отторженцы кембрийских и ордовикских пород. После установления в 50-х годах в палеозойской толще тектонических нарушений, в частности в Северо-Восточной Эстонии (Вахер. Пуура, Эрисалу, 1962), некоторые геологи (Саммет, 1961 и др.) стали объяснять образо вание Синих гор тектоническнми движениями земной коры. В последнее время обычюо считают, что тектонические нарушения явились только предпосылкой к формированщня СиЕих гор, но сами они представляют собой напорную конечную морену (Каяк, 1963; Орвику, 1960a; Maasik, 1961; Kajak, 1964).

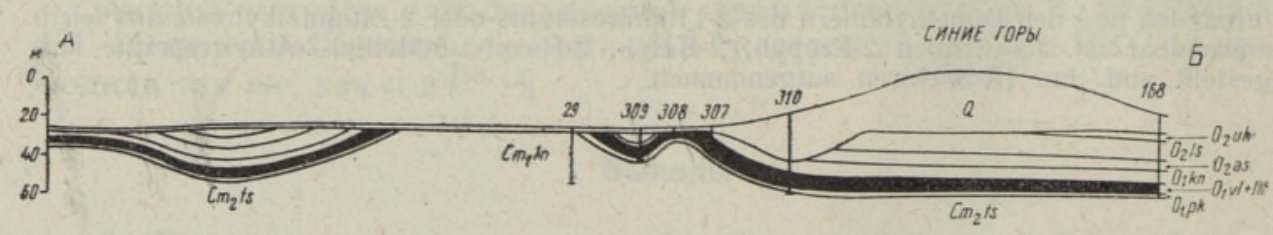

Рнс. 1. Разрез складкообразного поднятия севернее Синих гор по В. Пуура, Р. Вахеру, Т. Кууспалу и Э. Эрисалу:

Местоположение разреза - на рис. 2.

В окрестности Синих гор коренные породы представлены карбонатными и кластическими осадками ордовика, залегающими на песчаноглинистых породах кембрия. Район Синих гор расположен в зоне тектонических нарушений северо-восточного простирания, пересекающей всю территорию республики от Нарвы до Пярну (Орвику, 1960б). Севернее Синих гор установлено (Вахер, Пуура, Эрисалу, 1962) складкообразное поднятие (рис. 1), в осевой части которого выходят песчано-глинистые отложения нижнего ордовика и нижнего кембрия. По данным Р. Вахера и А. Мардла (1969), геологическая структура описываемого района характернзуется наличием вытянутых гребневидных складок широтного, 


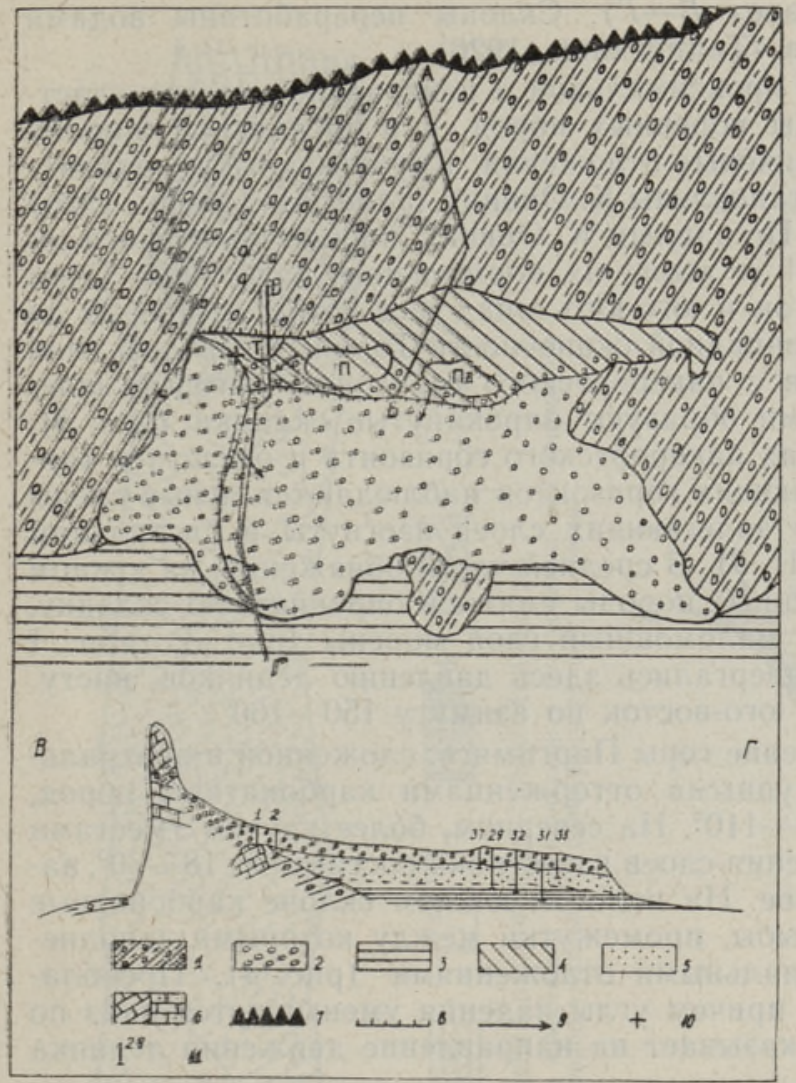

Рис. 2. Геоміорфологическая схема окрестности вайвараских Синих гор и разрез через холм Торнимяги полинии $B-\Gamma$ (увеличение в 25 раз):

1 - моренная равнина и морена (в разрезе $B-\Gamma) ; 2-$ флюнногляциальная дельта и ее гравийно-галечные отложения: 3 озерно-ледниковые равнина и отложения: 4 - напорная конечная морена; 5 - песчаные отложения флювноглящиальнов дельты; $6-$ плыбы известняков и песчаников; 7 - СевероЭстонский глинт; 8 - уступы н обрывы; 9 - направление падения слоев флюниоглящиально дельты: 10 - местоположенне разреза, нзображенного на рис. 3: 11 - буровые скважнны н их номера.

а восточнее Синих гор - северо-восточного простирания. Высота складок по кровле пакерортского горизонта нижнего ордовика при длине $1-3 \kappa м$ и ширине $0,1-0,7 \kappa м$ достигает 30 м. В ядрах антиклинальных складок выходят песчано-глинистые отложения нижнего кембрия. Интересной особенностью этих структур является уменьшение нх высоты сверху вниз. Структурным бурением севернее Синих гор в фундаменте тектонических нарушений не обнаружено. Отклонений от нормального залегания нет и в низах разреза осадочных пород, начиная с ломоносовской свиты. В современном, рельефе описанные выше струкгуры не выражены или выражены слабо. Генезис рассматриваемых структур неясный, возможно тектонический.

В рельефе поверхности коренных пород описываемого района наиболее крупным элементом является Северо-Эстонский глинт, расположенный в 2-3 км севернее Синих гор (рис. 2). Относительная высота уступа глинта здесь $20-35$ м. Западнее Синих гор находится глинтовая бух та Сытке. В пределах Северо-Эстонского плато рельеф поверхности коренных пород постепенно повышается в южном направлении, образуя у Синих гор и южнее их возвышение широтного простирания с относительными высотами 5-8 м. Кроме того, в рельефе поверхности коренных пород намечается ряд более мелких понижений и повышений меридионального и широтного направлений с относительными высотами от 2.5 до 5,0 м. Они расположены в основном южнее Синих гор.

Сами Синие горы представляют собой ориентированную в широтном направлении гряду из трех крупных холмов общей длиной около $5 \mathrm{kM}$ (рис. 2). Абсолютная высота холмов с запада на восток следующая: Торнимяги - 70, Пыргухауамяги - 83 и Паргимяги - 84,5 м. Относительная высота холмов над окружающими озерно-ледниковыми абрадированными моренными равнинами колеблется от 40 до $50 \mathrm{\mu}$. Поперечный профиль гряды - асимметричный: северные (проксимальные) склоны 
круче южных (рис. 2, разрез $B-\Gamma$ ). Склоны переработаны водами позднеледниковых водоемов (Tammekann, 1926).

В строении Синих гор в проксимальной и центральной частях участвуют морены и отторженцы коренных пород, а в дистальной широко распространены водно-ледниковые отложения. Крунные глыбы ордовикских карбонатных пород установлены-K. Орвику (Jaansơn-Orviku, 1926) в составе всех трех холмов. По данным К. Орвику, породы азериского горизонта лежат здесь на 21 ми выше их нормального залегания. Слои наклонены на юго-юго-восток н юго-юго-запад под углом от $18-25$ до $60-70^{\circ}$. На южном склоне западной оконечности Торнимяги видны слои нижнего ордовика, начиная с пакерортского горизонта, которые залегают вертикально, а местами образуют опрокинутые складки (рис. 3). В песчано-глинистых породах пакерортского горизонта и отчасти в карбонатных породах надстилающих горизонтов наблюдаются ясные следы напора: верхи вертикально залегающих слоев изогнуты в дистальном направлении (рис. 3; табл. II, 3). В средней части обнажения, на южном склоне Торнимяги, где коренные породы смяты в опрокинутую складку, внутри складки обнаружен маломощный слой морены (рис. 3 ; табл. I $1,2)$. Коренные породы подвергались здесь давлению ледников, насту павших с северо-запада на юго-восток по азимуту $150-160^{\circ}$.

Не менее интересно строение горы Паргимяги, сложенной в центральной части несколькими крупными отторженцами карбонатных пород, опрокинутых под углом $100-110^{\circ}$. На северном, более крутом (местами свыше $60^{\circ}$ ) склоне углы падения слоев известняка составляют $18-30^{\circ}$, направление падения - южное. На пологом южном склоне карбонатные породы раздроблены на глыбы, промежутки между которыми заполненьі мореной и флювиогляциальными отложениями (рис. 4). Преобладает южное падение слоев, причем углы падения уменьшаются вниз по склону. Ориентация глыб указывает на направление движения ледника примерно с севера на юг.

Строение и состав четвертичных отложений, покрывающих отторженцы и заполняющих промежутки между ними, довольно изменчивы (рис. 4). В некоторых местах непосредственно на поверхности отторженцев залегает зеленая глинистая морена, которая в других местах Северо-Восточной Эстонии не обнаружена, Морена представлена зеленым, местами синевато-зеленым с фиолетовыми разводами глинистым алєвритом, по гранулометрическому составу мелкозема сходным с глинами лонтоваской свиты нижнего кембрия. Гравия в морене содержится всего несколько процентов, гальки установлены лишь у подошвы слоя, где они представлены вдавленными в морену карбонатными породами. Содержание обломков карбонатных пород в нижней части морены доходит до $60-70 \%$, а кверху сходит почти на нет. Высоко содержание обломков кембрийских пород. Из-за наличия среди гравия и гальки карбонатного материала описанная выше морена отличается от типичной предглинтовой морены, а также от линз нижней зеленой морены, включенных в верхнюю серую карбонатную морену (рис. 4). Возможно, что зеленая морена покрывала поверхность коренных пород уже до наступания последнего ледника и была захвачена ледником вместе с отторженцами.

Между нижней и верхней моренами залегают флювиогляциальные отложения, представленные косослоистыми песками, гравием и галечником. Линзы песчано-гравийных отложений встречаются также в верхней серой морене. Мощность их до 0,5 $м$, протяженность около 5-6 $м$.

Верхняя серая морена, в нижней части грязно-бурая, сложена в основном плохоокатанными обломками карбонатных пород с преобла- 

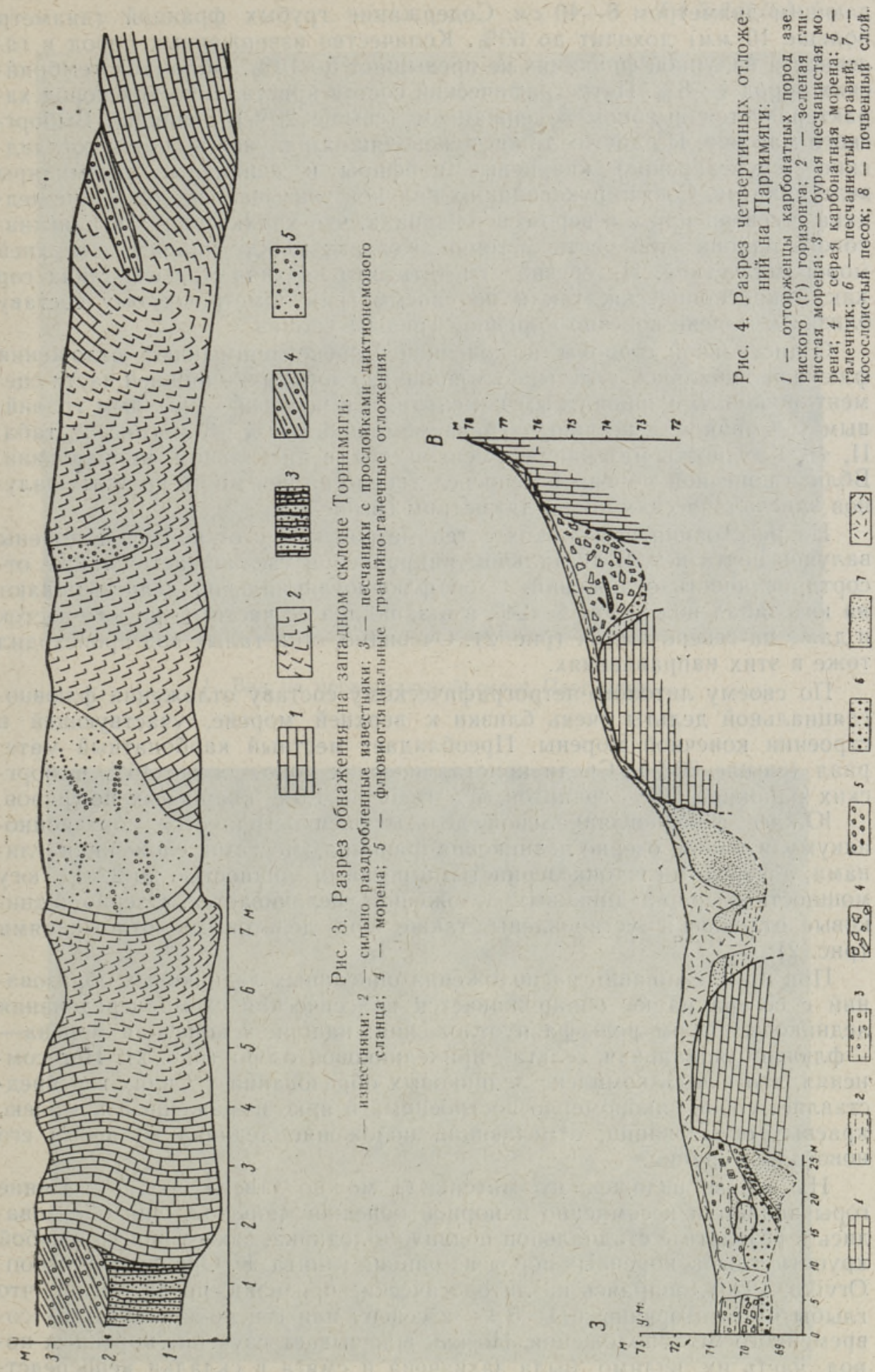

产尝

$\sum_{\infty}^{1}$

空

刃․

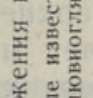

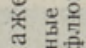

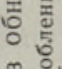

ఖँ

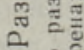

வ

ญ

$=10$

兴

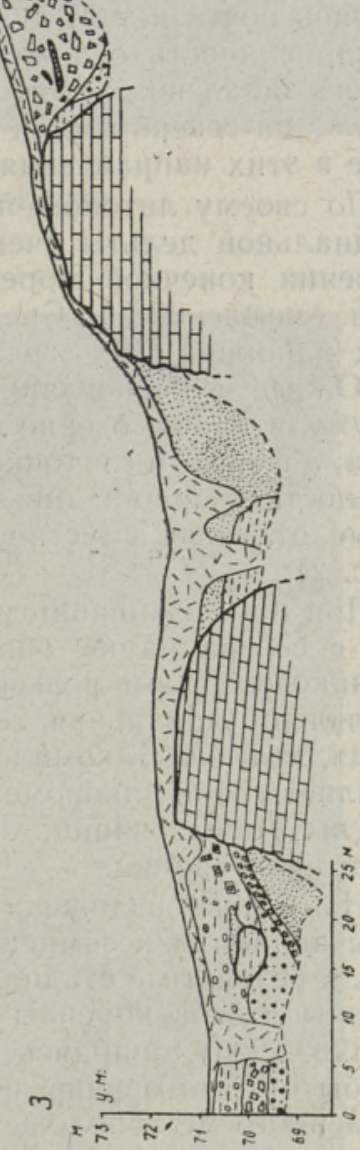

$\therefore$

$\because \div$

$0^{\circ}$

$\left[\begin{array}{l}10 \\ 6 \\ 10 \\ 10\end{array}\right.$

a

HB 
дающим диаметром 8-40 см. Содержание грубых фракций (диаметр больше 10 ммј доходит до $60 \%$. Количество изверженных пород в галечной и валунной фракциях не превышает 5-10\%. Обломков кембрийских пород $1-8 \%$. Петрографический состав кристаллических пород характеризуется высоким содержанием (свыше 20\%) рапакиви Выборгского массива. Из других типов руководящих валунов найдены гогландские (суурсаарские) кварцевые порфиры и единичные экземпляры хельсинкитов. Состав руководящих валунов указывает на движение ледника с севера или с северо-северо-запада, что характерно для приглинтового района этой части Эстонии. Контакт между нижней и верхней моренами четкий. Интересно отметить, что верхняя морена Синих гор как макроскопически, так и по своему гранулометрическому составу близка к морене конечно-моренной гряды Куремяэ.

С дистальной стороны к конечной морене примыкают отложения флювиогляциальной дельты, состоящие из слоистых, в нижней части сцементированных карбонатным цементом, а в верхней - рыхлым гравийным галечником и песчаным гравием мощностью $1-3$ м (рис. 2 ; табл. II, 4). Крупность материала уменьшается в дистальном направлении. Вблизи конечной морены и непосредственно на ней много крупных валунов кристаллических пород диаметром свыше 1 $м$.

На расстоянии нескольких сотен метров к югу от конечной морены валунов почти нет. В дистальном направлении увеличивается также отсортированность отложений. Слои флювиогляциальной дельты падают на юго-запад под углом $8-24^{\circ}$, а в западной ее части - на юго-восток и даже на северо-восток (рис. 2). Очевидно, сток талых вод происходил тоже в этих направлениях.

По своему литолого-петрографическому составу отложения флювиогляциальной дельты очень близки к верхней морене, участвующей в строении конечной морены. Преобладает местный карбонатный мате риал (свыше 80\%). Среди кристаллических пород около $45 \%$ выборгских рапакиви, $36 \%$ гранитов, $7 \%$ гнейсов, 1,5\% кварцевых порфиров.

Южнее флювиогляциальной дельты распространяется абразионноаккумулятивная озерно-ледниковая равнина, местами сложенная глинами, алевритами и тонкозернистыми песками мощностью до 2 м. К югу мощность озерно-ледниковых отложений увеличивается. Озерно-ледниковые отложения установлены также под дельтовыми отложениями (рис. 2).

При прослеживании расположения описанных ледниковых образований с севера на юг обнаруживается классическая схема чередования ледниковых форм рельефа и отложений: напорная конечная морена- флювиогляциальная дельта-приледниковое озеро (рис. 2). Нет сомнения, что и весь комплекс ледниковых образований у Синих гор представляет собой закономерно построенный и ярко выраженный комплекс краевых образований, отмечающий положение ледника во время его нового наступания.

На основе изложенного материала можно утверждать, что Синие горы являются несомненно напорной конечной мореной. Они образовались в результате стадиальной подвижки ледника, захватившего с собой крупные глыбы коренных пород из района глинта. К. Орвику (JaansoonOrviku, 1926), опираясь на литологические признаки, предполагает, что глыбы были оторваны в $4-5 \kappa м$ к северу или северо-западу от нх современного местоположения. Но как показывает изучение коренных пород, часть их, видимо, была захвачена и смята в складки ғепосредствен:но на месте коренного залегания. Следует согласиться с К. Орвику (1960а) и К. Каяком (1963), что образованию напорной конечной морены 


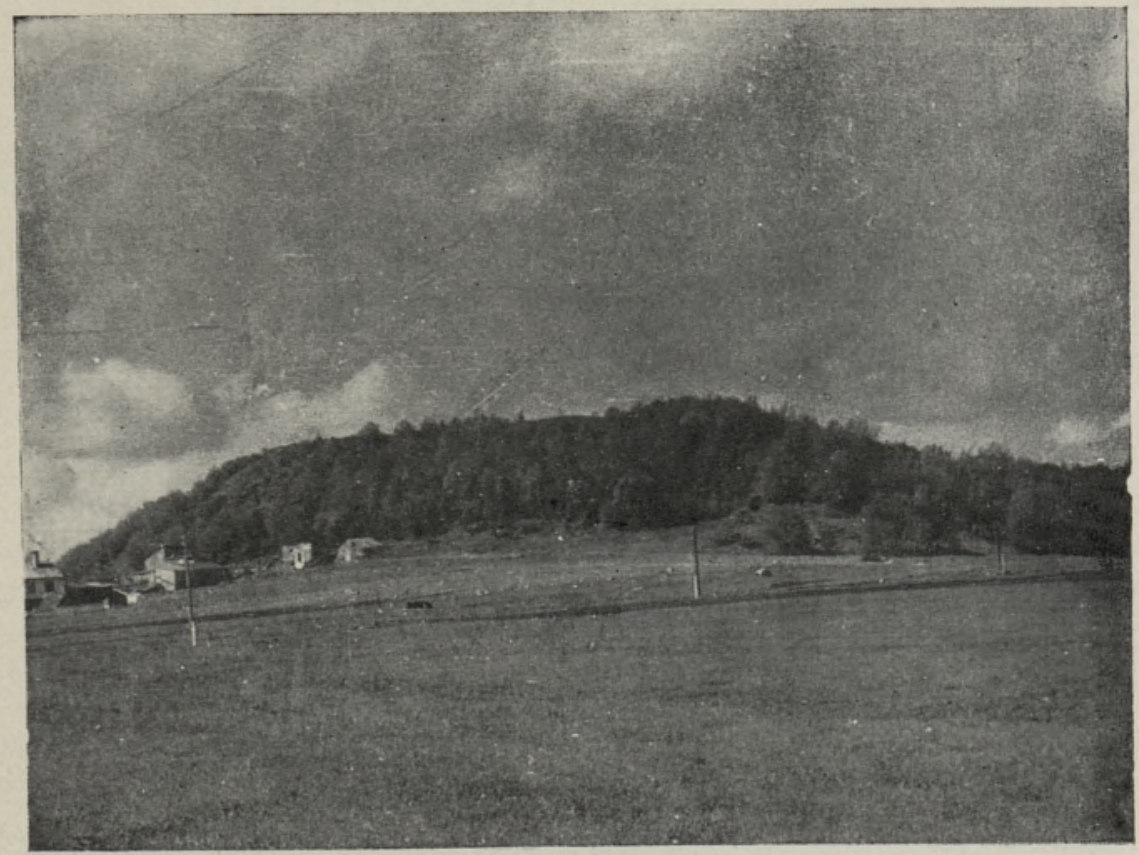

1. Вид на проксимальный склон Паргимяги.

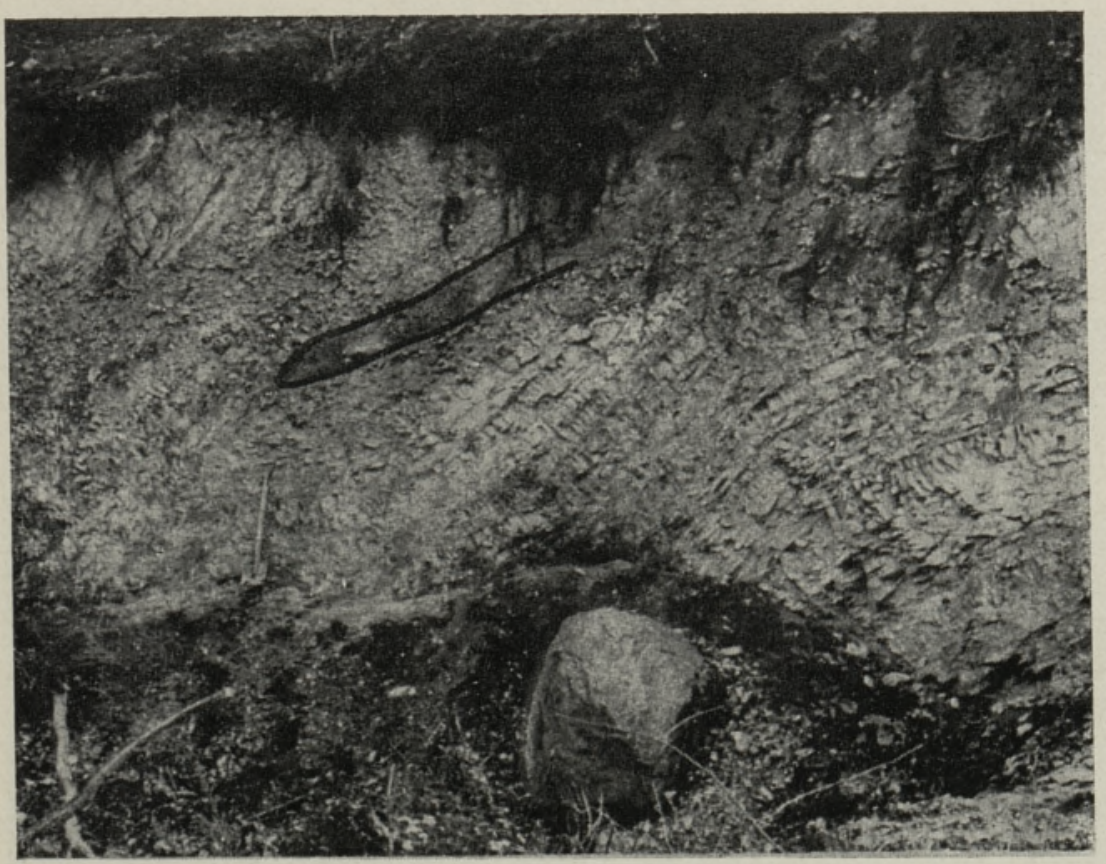

2. Опрокинутая складка в обнажении на западном склогіе Торнимяги. Внутри складки видна линза морены (оконтурена). 


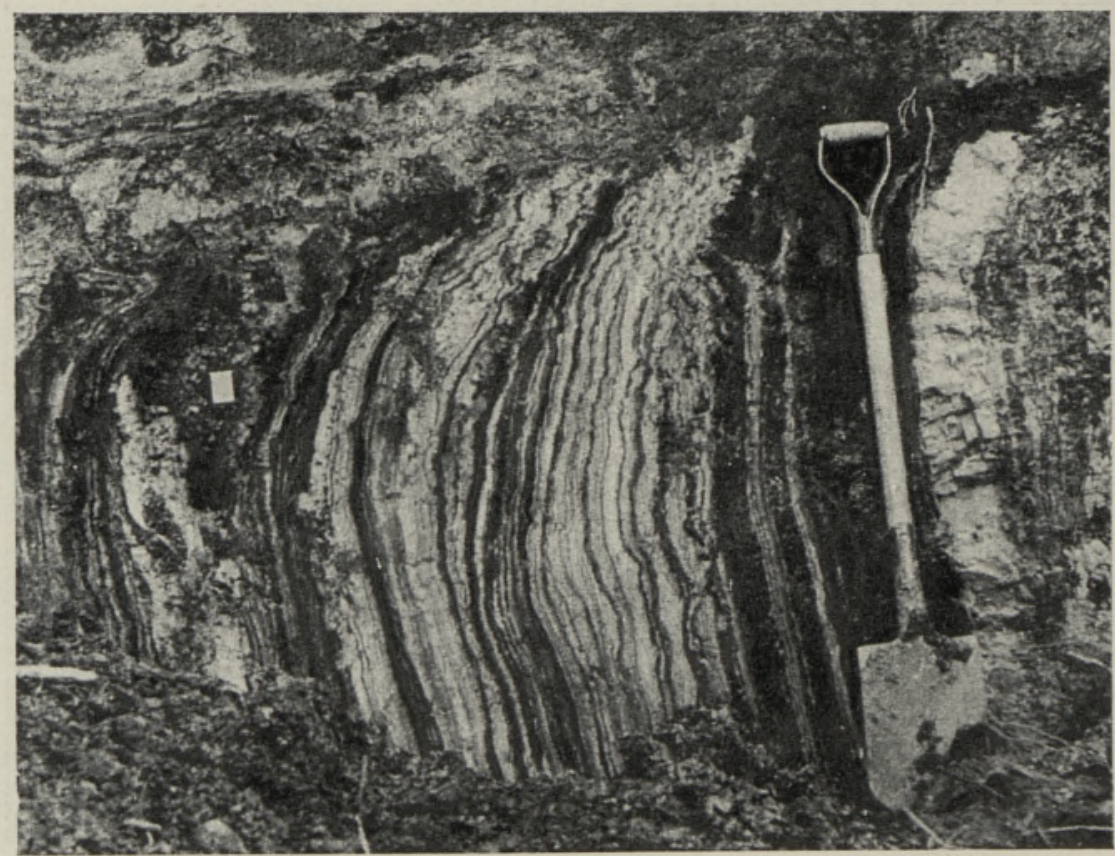

3. Следы напора ледника в песчано-глинистых отложениях пакерортского горизонта, Направление движения ледника слева направо.

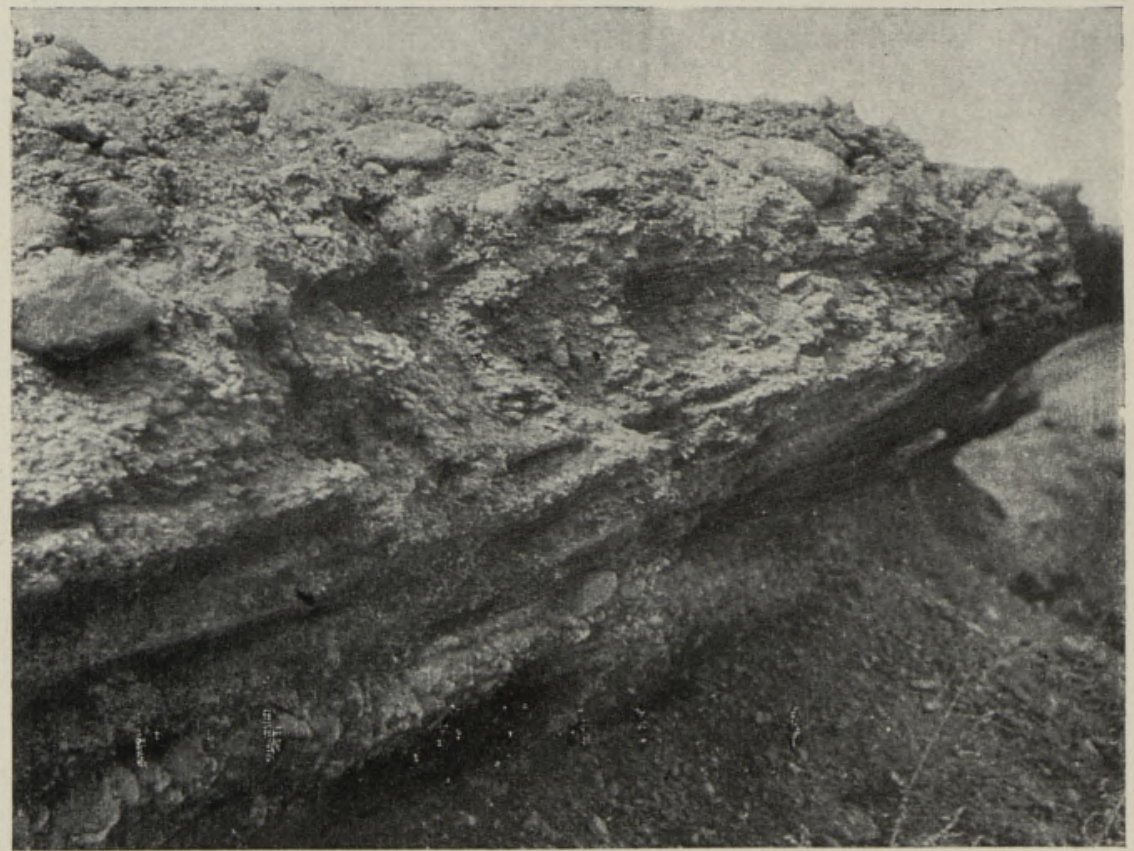

4. Сильно сцементированные гравийно-галечные отложения флювиогляциальной дельты. Падение слоев юго-западное. 
содействовали тектонические нарушения, установленные в окрестности Синих гор. К. Орвику (1960а) высказал интересную мысль о том, что поднятие кембрийскнх глин может быть обусловлено напором льда на уступ глинта при его стадиальном наступании. Это вполне возможно, если учесть общее тектоническое строение района, отсутствие глубинных нарушений и пластические свойства глин, залегающих под маломощным покровом песчаников и известняков.

В своем движении южнее глинта ледник, упираясь в образовавшееся таким образом возвышение в коренных породах, раздробил его и смял в складки. Возникшие перед краем льда крупные холмы препятствовали дальнейшему продвижению ледника на юг. После стабилизации ледникового фронта перед краем льда накопились флювиогляциальные и озерно-ледниковые отложения.

Краевые образования вайвараских Синих гор продолжаются в восточном направлении у Лаагна (Tammekann, 1926; Orviku, 1930), где также распространены конечные морены и водно-ледниковые образования. В этом же районе К. Орвику (Jaansoon-Orviku, 1926) установлен еще ряд отторженцев или гляциодислокаций. Возможно, что к юго-западу краевые образования Вайвара-Лаагна продолжаются в виде водноледниковых образований у Ийзаку-Иллука, как это предполагал уже Х. Хаузен (Hausen, 1913).

\section{ЛИТЕРА Т РА}

В ахер Р. М., М а рдла А. К. 1969. Опыт нзучения тектонического строения участка Синимяз (Северо-восточная Эстония) методом электроразведки. В кн.: Тр. по региональной геологин. Рига.

В ах е р Р. М., П у у р а В. А., Э р и с а л у Э. К. 1962. О тектоническом строении северовосточной Эстонии. Тр. Ин-та геол. АН ЭССР, $\mathbf{X}$.

Каяк К. Ф. 1963. О краевых ледниковых образованиях юго-восточной Эстонии. Тр. Ксм. по изуч. четверт. пер., XXI.

Мар ков К. К. 1931. Развитие рельефа северо-западной части Ленинградской области. Тр. Главн, геол, разв. упр. ВСНХ СССР, вып. 117.

О р в и к К. К. 1960а. Некоторые вопросы геоморфологии Эстонии. Матер. II геоморф. совещания. М.

О рвику К. К. 1960б. О неотектонических движениях в Эстонской ССР на основе геологических данных. В сб.: Матер. совещ. по вопр. неотект. движ. в Прибалтике. Тарту.

С ам м е Э. Ю. 1961. Некоторые вопросы четвертичной геологии и геоморфологии западной части Ленинградской области. В сб.: Палеогеография четвертичного пернода СССР (K VI конгрессу ИНКВА в Польше). М., изд. МГУ.

Gr a n̈̈ J. G. 1922. Eesti maastikulised üksused. Loodus, nr. 2.

$\mathrm{Hausen} \mathrm{H.} \mathrm{1913.} \mathrm{Ober} \mathrm{die} \mathrm{Entwicklung} \mathrm{der} \mathrm{Oberflächenformen} \mathrm{in} \mathrm{den} \mathrm{russischen} \mathrm{Ost-}$ seeländern und angrenzenden Gouvernements in der Quartärzeit. Fennia, 34, 3.

.J a a n s o o n-O rviku K. 1926. Rändpangaseid Eestis. Loodusuurijate Seltsi Aruanded, XXXIII, 7.

K a ja k K. 1964. Peipsi nõo geoloogiast ja geomorfoloogiast. Eesti Geograafia Seltsi Aastaraamat, 1963, Tallinn.

M a a s i k V. 1961. Kirde-Eesti aluskorra ja aluspōhja struktuuride uurimine gravimeetrilise meetodiga. ENSV. TA Toimet., Füüs.-matem. ja Tehn. Tead. Seeria, 10, nr. 4.

O r viku K., 1930. Die Glazialschollen von Kunda-Lammasmägi und Narva-Kalmistu (Eesti). Geol. Inst. Toim., nr. 23.

T a m m eka n n A. 1926. Die Oberflächengestaltung des nordestländischen Küstentafellandes. Acta et Comm. Univ. Tartuensis, A. IX.

Ннститут геологии

Академиі наук Эстонской ССР
Поступила в редакцию 22/XI 1968 


\section{A. MIIDEL, U. PAAP, A. RAUKAS, E. RAHNI}

\section{VAIVARA SINIMÄGEDE (KIRDE-EESTI) TEKKEST}

Esitatakse uusi andmeid Vaivara Sinimägede (tahvel I, 1 ) ehitusest.

Tornimäe läänenõlval paljanduvad alamordoviitsiumi kihid on vertikaalses asendis, kohati koguni kurrutatud (joon. 3). Kihtide lasumuse detailid selgete survejälgede näol (tahvel II, 3) ja moreeniläätse olemasolu kurdude vahel (tahvel I, 2) viitavad lasumusrikete glatsiotektoonilisele olemusele. Seda arvamust toetavad ka lubjakivipangaste lasumuse iseloom ja kvaternaarsete setete läbilōige Pargimäel (joon. 4).

Sinimägede distaalsel nõlval esineb fluvioglatsiaalne delta (joon. 2, tahvel II, 4), mis läheb üle jääjärveliseks tasandikuks (joon. 2). Seega moodustab Sinimägede liustikuliste pinnavormide ja setete kooslus seaduspärase ehitusega mandrijää servamoodustistekompleksi.

Mitmed uurijad käsitavad Sinimägesid tektooniliste pinnavormidena. Olalesitatu põhjal aga toetavad autorid varem avaldatud arvamust Vaivara Sinimägede glatsiaalsest tekkest. Kōnesolev seljak kujutab endast liustiku pealetungil tekkinud survelist otsamoreeni, mille teket soodustasid Sinimägedest pōhja pool ordoviitsiumi ja kambriumí setteis kindlaks tehtud lasumusrikked (joon, 1), mis arvatavasti on tektoonilise päritoluga.

\section{A. MIIDEL, O. PAAP, A. RAUKAS, E. RAHNI}

\section{ON THE ORIGIN OF THE VAIVARA HILLS (SINIMÄED) IN NE ESTONIA}

The authors present new data on the structure of the Vaivara Hills (Table I, 1).

The Lower Ordovician beds outcropping on the western slope of Hill Tornimägi are placed vertically, and folded in places (Fig. 3). The details of bedding, revealing clear traces of pressure (Table II, 3) and the existence of till lenses between the folds (Table I, 2) point to the glaciotectonic character of the dislocations. This stafement is also supported by the character of the bedding of limestone strata and by the section of the Quaternary sediments on Hill Pargimägi (Fig. 4).

The fluvioglacial delta occurring on the distal slope of the hills (Fig. 2, Table II, 4) passes into a limnoglacial plain (Fig. 2). Thus, the assemblage of the glacial relief forms and deposits of the Vaivara Hills composes a complex of glacial marginal formations of a regular character.

The Vaivara Hills have been treated as tectonic forms by various geologists. However, on the grounds of the above-mentioned data, the authors of the present study are in favour of a previously expressed opinion on the glacial origin of those hills. The range referred to represents a push end-moraine formed during the advance of the glacier. Its formation was favoured by the dislocations in bedding (Fig. 1), stated in the Ordovician and Cambrian deposits northwards of the Vaivara Hills, which are probably of a tectonic origin. 